\title{
Incident at Military Village No. 19
}

LAST week the Soviet Union for the first time admitted that an outbreak of some killer infection occurred last year in Sverdlovsk. Replying to a question from the US State Department, the Soviet authorities confirmed that an outbreak of anthrax did occur, but maintained that the disease was caused by poor food handling, not by bacteriological warfare agents as rumoured in the West. Since the Soviet Union has signed the international convention banning the use of such agents, this denial comes as no surprise. What is perhaps most significant is that the Soviet authorities have admitted that some bacteriological incident did take place after almost a year of "no comment" or "nothing happened".

Sverdlovsk, on the eastern side of the Urals, is a "closed city" to which foreign visitors are not admitted. Local information reaching the West is necessarily at least second-hand, and it would be unwise to give undue credence to every detail. The details on which the US State Department based its enquiry seem to be drawn from a single Russian underground source albeit one which claims to emanate from Sverdlovsk.

However, even one such document is worth taking seriously - if not as evidence of what occurred, at least as a pointer to local fears and responses.

According to this document, in April 1979 there was an escape of a bacterial strain called V-21 in "Military Village No. 19 " on the south-western outskirts of the city. The bacteria were carried by a north wind to the village of Kashino, with only a negligible amount reaching Sverdlovsk proper.

Casualties were mainly among the military and civilian residents of "Military Village No. 19', inhabitants of Kashino, and workers at the local ceramics plant. Death typically occurred some 1-3 hours after hospitalisation, following a fever of over $42^{\circ} \mathrm{C}$. Special army nurses wearing protective clothing were brought in. Bodies of those who died were not returned to the relatives for funeral ceremonies. The total death toll was unofficially estimated at over 1,000 .

Official local reaction, says the report, took the form of placebo messages, which gradually escalated from "nothing is happening" at the beginning of the outbreak, to "nothing happened, and anyway, don't panic, it is all localised and under control" towards the end. Finally, the streets of Kashino village were paved with asphalt, apparently to neutralise remaining infection.

Equally circumstantial are rumours emanating from Slovakia of a similar incident involving a Soviet military base.
Here, however, there were no fatalities, only a widespread outbreak of what appears to be a new form of infective hepatitis. According to local sources, an area of central Slovakia some $70 \mathrm{~km}$ by $30 \mathrm{~km}$ is regularly used by Soviet paratroopers as a training ground. Some time in late August or early September it is alleged that one such training exercise led to the accidental discharge of bacteriological weapons. The military casualties were said to be too numerous for the existing army facilities, and the

overflow was taken to civilian hospitals in Poprad and Spisska Nova Ves.

Inevitably some of the virus was borne by the wind outside the training ground, and "several thousand" of the civilian population also succumbed. The Slovak sources stress that this does not appear to have been intended as a killer weapon rather one to debilitate and incapacitate the local population and thus minimise resistance before the arrival of an unwished for "peace-keeping" force.

Vera Rich

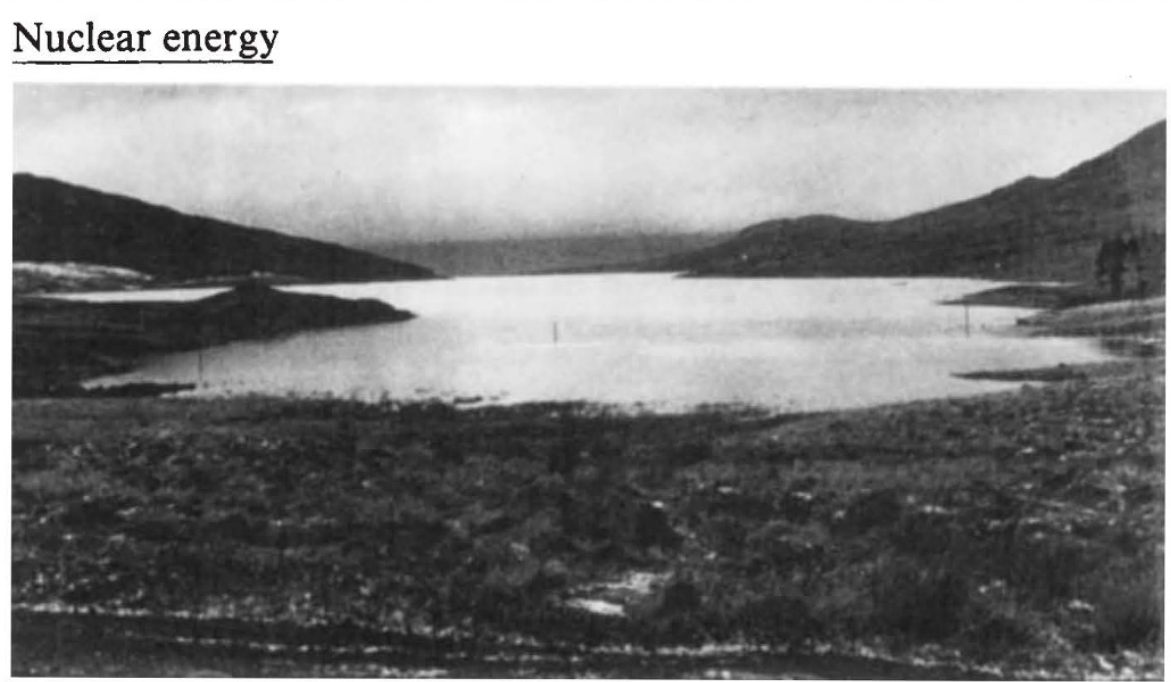

Loch Doon, Scotland: UKAEA refused test drilling permission

\section{Power dissenters through Europe}

AN overwhelming majority of Swedes voted against any further extension of nuclear power in a special advisory referendum last Sunday. By a combined vote of $76 \%$ to $19 \%$ with $5 \%$ undecided, the electorate registered its approval to phase out Sweden's present nuclear programme within 25 years. Thirty nine per cent of the voters supported the Centre Party-Communist proposal to dismantle the programme within 10 years, $37 \%$ supported the Social Democrat-Liberal proposal to use present and planned capacity for 25 years as an emergency meausre only, and $19 \%$ supported a Conservative option that would leave the door open for the development of uranium mining and the fast breeder.

- Swiss voters in the village of Hagedorf in the north west canton of Solothurn may have blocked effectively further nuclear development in Switzerland last week by refusing to give permission for test drilling for nuclear waste disposal. The 2,500 villagers rejected proposals by the Statebacked company Nagra to drill for waste disposal sites by a 3-1 margin, despite having voted in favour of the government's energy programme last year.

- French residents in the Brittany towns in cap Sizun claimed a victory last week when the provincial prefect at Quimper freed seven anti-nuclear demonstrators arrested during running battles with the police at protests on 29 February. A crowd of several thousand residents shouted "we have won" at the 1,500 police stationed around the Quimper courthouse. M. JeanMarie Kerloc'h, mayor of Plogoff, called the decision "comforting". After the court decision and the pre-trial mass demonstration of 40,000 people, it is now widely believed that the central government will be forced to back down from its attempt to impose a complex of four nuclear reactors on the strongly nationalistic Breton people.

- In Finland 5,000 demonstrators, including a large number from the countryside, marched through Helsinki last week to show their solidarity with Swedish anti-nuclear protests and their opposition to the construction of a Soviet 